\title{
Erratum: Body composition study by dual-energy $x$-ray absorptiometry in familial partial lipodystrophy: finding new tools for an objective evaluation
}

Cynthia M Valerio ${ }^{1,4^{*}}$, Lenita Zajdenverg ${ }^{2}$, Jose Egidio P de Oliveira ${ }^{2}$, Patricia B Mory ${ }^{3}$, Regina S Moises ${ }^{3}$ and Amélio F Godoy-Matos ${ }^{1}$

Following publication of this manuscript [1] it was discovered that Dr Moises name had been inadvertently misspelled. This has now been corrected in the author list above. The authors apologise for any inconvenience this may cause.

\section{Author details}

'Metabolism Unit, Instituto Estadual de Diabetes e Endocrinologia, Rio de Janeiro and Catholic University, Rio de Janeiro, Brazil. ${ }^{2}$ Department of Nutrology, Universidade Federal do Rio de Janeiro, Rio de Janeiro, RJ, Brazil. ${ }^{3}$ Division of Endocrinology, Universidade Federal de Sao Paulo, São Paulo, SP, Brazil. ${ }^{4}$ Instituto Estadual de Diabetes e Endocrinologia, Rua Moncorvo Filho 90 - Centro, Rio de Janeiro RJ CEP 20211-340, Brasil.

\section{Reference}

1. Valerio CM, Zajdenverg L, de Oliveira JEP, Mory PB, Moyses RS, Godoy-Matos AF. Body composition study by dual-energy $x$-ray absorptiometry in familial partial lipodystrophy: finding new tools for an objective evaluation. Diabetol Metab Syndr. 2012:4:40.

\footnotetext{
* Correspondence: dracynthiavalerio@gmail.com

${ }^{1}$ Metabolism Unit, Instituto Estadual de Diabetes e Endocrinologia, Rio de Janeiro and Catholic University, Rio de Janeiro, Brazil

${ }^{4}$ Instituto Estadual de Diabetes e Endocrinologia, Rua Moncorvo Filho 90 Centro, Rio de Janeiro RJ CEP 20211-340, Brasil

Full list of author information is available at the end of the article
}

Submit your next manuscript to BioMed Central and take full advantage of:

- Convenient online submission

- Thorough peer review

- No space constraints or color figure charges

- Immediate publication on acceptance

- Inclusion in PubMed, CAS, Scopus and Google Scholar

- Research which is freely available for redistribution 